\title{
Expressive Devices in the Language of English- and Spanish-Speaking Youth
}

\author{
Félix Rodríguez González and Anna-Brita Stenström \\ University of Alicante / University of Bergen \\ frodriguez@ua.es / ab.stenstrom@telia.com
}

\begin{abstract}
The aim of this paper is threefold: first, to introduce the topic of youth slang by giving an overview of its main characteristics; second, to show the different word-formation processes that slang has to make the speaker's message more expressive; and third, to study the extent to which these two aspects are reflected in two corpora representing London and Madrid youth language. The present study is based, primarily, on an inventory of the top ten 'proper' and 'dirty' slang words in each language variety with particular emphasis on the speakers' age and gender, and, secondarily, on the entire corpus data, which showed great agreement with the features outlined in the overview of the main characteristics of youth slang, while the most obvious word-formation mechanisms turned out to be related to change of form and change of meaning.
\end{abstract}

\section{Introduction}

Is youth language poor language? The answer to this question is not straightforward and should be properly nuanced. For purely biological reasons, youth language is immature and reflects less linguistic competence than adult language. This is especially true for the language of teenagers, the 13 to 19 year-olds. However, with regard to slang, the slightly older group, represented by 19 to 25 year-old 'young adults', have been developing a large vocabulary in the last few decades, especially since the 1960s, the age of the youth revolution. If young people until that time imitated adults in clothing, manners and 
language, we have seen the reverse happening ever since. Adults of all ages, both men and women, have been trying to adopt a young appearance and lifestyle, which includes the use of language, and slang in particular. Consequently, the development of youth slang is of crucial interest not only to linguists, but also to the population at large, given that youth slang has a tendency to be adopted in the standard language. Since new trends generally first appear in large cities, this is where the development of youth slang is of utmost interest.

The data used in this article, apart from the corpora and field work done by the authors, has been mainly drawn from various sources, including Eble (1996) and the dictionaries by Green (1998) and Thorne (1997). Special attention has been paid to the label 'youth' or 'adolescent' used in them, although with the passing of time some words and expressions may have gone into oblivion, and others may have been integrated into the general language. In addition to these data, two corpora of spontaneous teenage conversation were consulted, The Bergen Corpus of London Teenage Language (COLT) and the Corpus Oral de Lenguaje Adolescente de Madrid (COLAm).

\section{The nature and creativity of youth slang}

\subsection{General remarks}

There seems to be a general consensus among linguists and dictionary makers alike that the most important aspect of slang is that it represents 'language use below the level of stylistically neutral language usage' (Andersson and Trudgill 1990: 69), that it consists of 'very informal language that includes new and sometimes not polite words and meaning' (Longman Dictionary of Contemporary English 1987: 987), and that taboo words, used figuratively, should be regarded as slang.

Slang is first and foremost associated with a social group, as its raison d'être is to establish a feeling of solidarity among its speakers. Those belonging to the underworld, or a counterculture, and groups which are socially stigmatized develop a kind of cryptic slang as a sign of identification. But generally what prevails in today's slang is humour, a playful search for fun in order for the speaker to appear clever and witty. The humour and irony in youth slang often reflect a kind of rebellion, giving rise to a subversive language, an 'anti-language', as it implies values set against the established society. Consequently, the language of youth groups becomes highly connotative, full of synonyms for concepts that are very dear to them and related to a few semantic fields, such as love, drugs, fun and student life. What matters is not the denotative meaning of the words, but their associations and their connotations.

While the standard language appears fairly stable, slang is burgeoning and lends itself to more linguistic creativity, although most of its creations are ephemeral. And this is especially true of the language of adolescents and young adults. As Eckert (1997: 52) states, 
Adolescents are the linguistic movers and shakers, at least in western industrialized societies, and, as such, a prime source of information about linguistic change and the role of language in social practice.

A distinction can be drawn between activity spheres controlled by adults, for example in schools and colleges, where 'student slang' arises, and the 'independent' activities based on some form of youth (sub)culture.

\subsection{Variation}

As argued in Rodríguez (1998: 252), because of the social conditions of its speakers, English has a larger supply of slang words than Spanish, and the same applies to youth slang. Since youth are not a homogeneous group, a lot of variation can be expected if we consider different sociolinguistic parameters. There is a core vocabulary that is fairly common, but there are marked differences when it comes to different youth subcultures and different regions and language varieties, or different subject matters and technolects, as reflected in students' slang, soldiers' slang, etc. According to Thorne (1997: vi), American youths have traditionally been more prolific in coining new slang than their British counterparts. This is reflected in dictionaries like Green's Dictionary of Slang (1998).

In relation to gender, male speakers contribute with more coinages to their lexicon and use slang relatively more often than female speakers, a tendency that is also noticed with respect to teenage slang (Stenström et al. 2002: 73-74). As to social status, slang, and youth slang in particular, usually originates in marginal groups and is predominantly used by the working classes, although it tends to surpass social boundaries and spread to other sectors of the population. Occasionally, a specific slang variant arises in certain upper class circles. A good example is 'Valley Girl talk' or 'Valspeak', typical of the spoiled teenage girls of California's San Fernando Valley, which spread across America in the 1980s. In Spain, similar features are found in the so-called lenguaje pijo (see Vigara 2002).

There is also variation when it comes to ethnicity. In American as well as in British English there is a distinct black teen slang, although some of its words cross over into general teenage slang. Black street culture in America, and especially the Jamaican influx into New York, has contributed to the creation of a rap and a hip vocabulary that is imitated all over the English-speaking world. Black British slang has drawn from North American and Caribbean sources, but now contributes its own terms, for instance touch down 'sexual success'.

\section{Linguistic mechanisms}

This section examines the main linguistic mechanisms that are at work in the creation of new expressive slang words, which often convey a humorous and ironic tinge and sort of 'anti-language' tone, reflecting the values of the youth, especially of those subcultures that stand out most clearly in their opposition to conventional society. These 
mechanisms will be mnemotechnically described as 'the $4 \mathrm{C}$ 's': change of form, change of meaning, change of code and change of register.

\subsection{Change of form}

The most visible criterion that allows us to identify a new word as slang in the language of the young, and in slang in general, is the change of its form. The signifier can be intentionally changed by different means: by abbreviation, lengthening, deformation and morphological substitution.

CLIPPING is a long-standing device by which only part of the original word is retained. Examples from American student slang are so-called 'back-clippings' (grad 'graduate', vibes 'vibrations', hyper' hyperactive') and 'fore-clippings' (brary 'library', rents 'parents', ted 'wasted' 'drunk'), and the singular clipping rotic (from romantic), where the initial and final syllables have been kept.

The slangy nature is reinforced when the clipped word incorporates spelling changes, such as alkie ('alcohol') and presh ('precious'), where the phonetic spelling has led to the substitution of a consonant in order to preserve the original pronunciation. The slangy nature is also highlighted when the abbreviation is reduced to only one syllable (brill 'brilliant', caff 'café'), and when the clipped word has neglected a linear segmentation and replaced a vowel. Examples are combo from combination, fave from favourite (a teenage girl's term used in teen magazines) or an added consonant, as in caffe (from café). Compare Sp. anarco (< anarquista 'anarchist') and manifa (< manifestación 'demonstration'). A notable colloquial abbreviation introduced in the $1960 \mathrm{~s}$ is represented by the agglutinated form coupla ('couple of') following its predecessor kinda.

Related to clipping is ELLIPSIS, in which whole words are left out, or suppressed within a phrase (hence the term 'suppressed mutilation'), since its meaning can be understood from the context. This fits in well with young people's fondness for a laconic way of speaking. Some salient examples are drop in, drop out (= 'into/out of conventional society'), come across ('surrender sexually') and go with ('go out together'), where a person is implied in the prepositional phrase, and the verbs carry, deal, use and smoke, where the name of a drug, or a drug in general, is easily understood.

Another shortening process is BLENDING, where two different words are fused. American student slang has trendinista $(<$ trendy + Sandinista) for a 'political or social activist who combines heightened political consciousness with stylish clothing', droned (< drunk + stoned $),$ scrump (< screw' + bump), bodacious, an 80s guy's way of describing an attractive young woman, especially one having large breasts $(<$ bold + audacious $)$. Some blends can be viewed rather as humorous word distortions, which recall similarly sounding expressions, such as (ex)squeezme for excuse me and screws me ('fuck me').

ACRONYMS (or initialisms) are extreme cases of abbreviation, coined for instance due to economy of space and time. Examples are $D J$ for 'disc jockey', used by pop fans, and ott 'over the top', to refer to something overdone or over-expressed. Occasionally, there 
is a cryptic motive, as in the names of drugs represented by their initial letter: $A$ for amphetamine, $C$ for cocaine, $E$ for ecstasy, $H$ for heroin or horse and $M$ for morphine.

Often, the motive for acronyms in youth circles is humour mixed with a preference for euphemistic expressions, as shown in some abbreviations referring to sex or love in American slang: $M D G$ for 'mutual desire to grope' or 'strong physical attraction', NTO for 'not the one' (i.e. a date who does not come up to expectations), $M L A$ for 'massive lip action', i.e. passionate kissing, $O P P$ for 'other persons' property', i.e. a male or female who is romantically committed to someone else, $V B C$ for 'visible butt crack', i.e. having the outline of one's buttocks showing through tight trousers, or revealing the top of one's buttocks due to wearing one's trousers lower than the waist.

Although less frequently, there are also acronyms whose letters are pronounced as a word, e.g. nail ('nice ass in Levis's'), denoting a 'well-built male', and the adjective phat ('physically attractive'), originally used to describe an attractive woman. Phat was coined in the 1960s on the US black campus as a deliberately skewed spelling of fat (Green 1998). Its popularity is well reflected in the numerous 'backcronym' meanings assigned to the word: 'Pretty, Hot, and Tempting', 'Pretty, Hot And Tight', 'Pretty, Hot And Thick', 'Pretty, Hot And Thin', 'Pretty Hot and Tasty', 'Perfect Hips and Thighs', 'Pretty Hips, Ass, Tits', and also as a general term of approval or admiration, especially used in pop culture. Occasionally, there are terms coined in a similar way, as a kind of 'acronymic compound', where the first syllables of two words are welded, as in ToBo ('totally bogus'), used in US teentalk to mean 'unpleasant, undesirable', or 'uncool', to use a slang synonym.

A phenomenon opposite to abbreviation is LENGTHENING,by which a segment is added to a simple word. A common slang ending is $-o$, as in duffo 'bad, inferior' (from BrE $d u f f$ 'worthless', 'useless), dumbo (from dumb 'stupid') and kiddo (from kid). The longer ending -blatt appeared on the US campus in the 1980s as a suffix of familiarity or endearment added to nouns (Green 1998); also American are -age, which became popular among older adolescents in the early 1990s (buffage, grindage, and tuneage), and -ski (finski 'a fin or five dollar bill'). Compare Sp. -iqui and -uqui in moderniqui (< moderno 'modern') and fiestuqui (< fiesta 'party').

Another feature leading to a change of word form is SUBSTITUTION of the ending. Illustrative examples are fella ('a young, trendy, desirable man'), used by girls and young women in the UK, from standard English fellow ('a male of any age or type'), and muso ('a music enthusiast; a pop musician').

Manipulation of the signifier can lead to the PERSONIFICATION of inanimate objects with a humorous effect. For instance, MDMA is implied in the English blend Madchester, coined in the 1980s, referring to a brief period in the late eighties when Manchester, rather than London, dominated the teen fashion, music and choice of drug consumption. Mad refers to the use of MDMA ('ecstasy'; Green 1998: s.v. Madchester). A prolific type of personification involving drug names is obtained through the expansion of the initials used as abbreviation, as in Miss Emma (for $M$ 'morphine') and Harry (for $H$ 'heroine').

RHYMING SLANG, whereby a word or phrase rhymes takes on the meaning of another word it rhymes with, has been traditionally used by Cockneys, but has been taken over by 
British youth to create terms such as Richard Gere for 'beer', Emma Freuds for 'haemorrhoids', and Douglas Hurd for 'turd'. 'Although rare, the phenomenon is found in Spanish in the soldier's slang of the last few decades: mesías, lavadora, berberecho ('a soldier soon to be demobbed') (cf. Rodríguez 2005: 13).

A most visible way of changing the form of the word is obtained by reversing a word, a phenomenon technically known as BACKSLANG. Backslang in English dates back to the Victorian era, when it was used in London as a secret means of communication mainly among petty thieves and street sellers. This kind of coinage is still used today in yob or yobbo (from boy) with reference to 'a rude, noisy and aggressive youth'. A variant of backslang is 'Pig Latin', whereby an affix, -ay or -way, yay or -hay, is added to the ending of the word, making its meaning more obscure (e.g. banana > ananabay). The reference to Latin is a deliberate misnomer, used to denote a strange foreign-sounding language. It is used by children and adolescents for fun or for keeping the meaning of the words secret from adults. In Spanish it is known as vesre (from revés 'back to front') and is mostly found in Argentinian lunfardo among young people and much less frequently in European Spanish, where we find, for instance, monja (< jamón 'ham') and bronca (< cabrón 'bastard').

\subsection{Change of meaning}

A word-forming device that is characteristic of slang, and of all anti-languages, is semantic transfer or change of meaning, especially by way of metaphor. As Halliday (1978: 175) points out, an anti-society is in its structure a metaphor of society, in the same way as an anti-language is a metaphor of language.

If we look closely at drug terms used by the young, we will notice that a good number of them have been subject to semantic transfer. By their nature, some of the terms reflect the tension between an anti-society and the established society. They are concepts that are tabooed or stigmatized by the establishment, which marginal groups re-name with inoffensive words drawn from ordinary communication and taken out of their usual contexts. This procedure was underlined by Marcuse (1972 [1969]: 41) when commenting on typical words from the hippy counterculture of the 1960s, such as acid for 'LSD', trip for 'doses and effects of LSD' and grass for 'marihuana'.

From a semiotic perspective, this re-contextualization of lexical items is not very different from the symbolic appropriation of ordinary objects by hippies and punks respectively. This transfer of meaning implies a break with the linguistic universe of the established society; it is the effect of a new outlook on life which leads to the building of a new language variety to define and communicate new values.

The de-sublimation of language does not stop with ordinary words but goes down to the scatological level. The extreme case of a break with the established standard language is the reversal of the traditional meaning of words, a process known in rhetoric as 'antiphrasis'. Black American English has been a customary provider of such words, some of which have been imitated all over the anglophone world. For instance, motherfucker came to mean 'excellent', 'winner'. Bad, wicked, awesome and brutal were used as terms 
of approval, meaning 'good', 'excellent', 'first-rate', just like totally (very) rude in the 1990 s, not to mention fucking A.

The subversive character of the philosophy which underlies the meaning of some metaphors is worth emphasizing. Some metaphors resort to the names of vegetables, such as grass, cotton, mushrooms and parsley, others to the names of animals, such as mule, turkey and monkey. Personification, with a touch of humour, is revealed in some names, as in AmE Jane, Juane, Juanita, Mary, Mary Ann, Mary Jane and Mary Warner for marijuana and Mama coca for cocaine (cf. Murray 1996: 118-119), corresponding to Sp. Madre. Theses slang names reveal a consecration of 'the forbidden'.

\subsection{Change of code}

In their search for expressiveness, young people resort to existing words and expressions drawn from other sociolects, which help to convey an exotic air. The following two courses of action are typical:

- 'DOWNWARD' CHANGES, from marginal sociolects, which are considered to have low prestige ('covert prestige'), such as the language of gypsies, prostitutes, delinquents, vagabonds, etc., in other words, the underworld, groups with a social stigma. In a similar vein, in today's American English, dialectal borrowings are common, for instance from Black English (e.g. fugly from fucking $+u g l y$ ) and from minorities such as Chicanos, who have contributed with words like chica, chiquita ('girl'), qué pasa? ('how are you?') and luego ('later'), not to forget expressions such as hasta la bye bye, adios amoebas, adios amigos ('good-bye, friends'), and hasty bananas ('hasta mañana'). These kind of ironic and humorous expressions emanating from Spanish are sometimes referred to as 'mock Spanish' in the literature.

- 'UPWARD' CHANGES, from prestige foreign languages which give rise to high prestige words ('foreignisms'), conveying 'overt prestige', such as silver plate from French $s$ 'il vous plait, bokoo 'very' from French beaucoup 'much, many' and o-ha, a Japanese slangy substitute (mostly used by teenage girls) for ohayoo ('good morning'). Spanish has traditionally imported words from English and French, for instance, anglicisms such as yoin (< joint 'marihuana cigarette') and trip ('drug') and calques such as bajar ('download') and correo caracol ('snail mail').

\subsection{Change of register}

ONOMASTICS is a lexical area that shows the profound changes that have taken place in youth language since the 1960s, changes that are especially noticeable in the names of music groups and their songs, which often reflect a countercultural ideology and an irreverent and aggressive tone. This tendency was most apparent in the names of many rock bands (especially punk groups) of the 1970s: Vice-Squad, Bad Manners, Misfits, The Mad, The Exploited, The Worst, Corrosion of Conformity, The Iconoclast, Wasted Youth. These groups presented themselves as mad, maladjusted, rude, vicious and marginal, in 
sum, the scum of society. The very name punk (literally, 'shit'), or the names of other music styles, such as funk (originally 'nasty-smelling') seem to form part of a special language of fantasy and alienation in which values are inverted and what is terrible is described as excellent (cf. Hebdige 1984: 162). Irreverence did not leave sexual references aside, as reflected in Sex Pistols and the name of other groups. This phenomenon did not only occur in Britain and the US; other countries like Spain reflected the same tendency, as shown in such names as La Polla Records (polla meaning 'penis'), Semen up and Sex Museum (cf. Rodríguez 2002: 53).

\section{Semantic fields, subject matters typical of youth creativity}

\subsection{Sex}

Sex has generated more slang terms than other areas; it is central to human behaviour, and the number of sexual activities that can be described with slang outnumber those from other semantic fields that are receptive to informal language, such as money, violence or inebriation. The metaphors involved are usually linked to humour: e.g. facerape ('kiss passionately'), coyote date ('an ugly girl'), cruise ('to move about with the intention of picking up a young girl/man'), doll ('girl'), boobs ('a woman's breasts' or 'girls/women as sexual objects') and party hat 'condom'. Sometimes the expression reflects simply a specialization of meaning, as in come across ('to dispense sexual favours').

\subsection{Food}

Food and gastronomy give rise to recurrent metaphors in youth language. Thus, in the language of British rave culture disco biscuits stands for 'Ecstasy tablets'. In American college slang a concept that recurs in student life, with the boom of cable MTV and home video, is 'someone who lies on the couch doing nothing', which has attracted several synonyms, such as coach potato, spud potato, sofa spud, sofa yam and veg. Corresponding Spanish expressions would be practicar sillón ball (literally, 'to play "armchair-ball"'), hacer tumbing (literally 'to play "lying down"'). Other English food concepts are go for sushi ('to kiss passionately'), bacon ('good-looking', 'sexy'), cheesy ('bad looking'), snackbar ('boyfriend or girlfriend'), dish ('attractive') and cheese ('someone or something unattractive').

\subsection{Drugs}

Drugs are a good breeding ground for lexical innovation. There are types of drugs such as speed ('any amphetamine-based stimulant') and grass, weed ('marijuana'); persons who use drugs such as freaky ('abnormal because of drug-taking', hence ' unusual, hippylooking'), pot-head and junkie ('heroin addict'); and states or feelings related to drug taking such as buzz ('excitement'), stoned 'intoxicated' (cf. Sp. colocado), trip ('experience that follows the taking of LSD or another hallucinogen'), tripped out, come 
down ('to be under the influence of LSD', etc.), downer ('tranquilizer'), high ('under the influence of drugs, suggesting pleasant experience') and flip (cf. Sp. flipar 'become very enthusiastic, excited', 'become infatuated with a person').

\subsection{Music}

Another field very much linked to the youth interest is music, which has given rise to many movements and styles, such as funk (originally, 'a pungent odour given off by a sexually aroused female', hence 'passionate soulful jazz music'), funky ('passionate, soulful'), punk ('worthless'), punk rock, rap and techno-rock; terms for individuals such as groupie, rocker, deejay or DJ ('disc jockey') and man (a form of address among Blacks and jazz musicians); and a variety of miscellaneous expressions such as and all that jazz ('and all the rest of it'), bummer ('depressing or frightening experience' and combo ('a jazz group, a small band'),

\subsection{Interrelation of lexical fields}

Drugs, music and sex are sometimes interrelated. These three areas constitute a well established trilogy which is reflected in language, where one can notice a series of associate metaphors.

Music and drugs are combined in the Spanish casete and estéreo, which apart from denoting two musical instruments are used to designate different amounts of hashish (one and two kilos respectively). Pink Floyd, the name of a music group is a type of LSD, with very pleasant connotations, but which also designates an injection of heroine or some other drug.

Words referring to sex and love and drugs are even more numerous, e.g. hooked on ('addicted to') (Sp. colgado and pillado). Such correspondences are not casual; there is a transition between the field of drugs and others such as prostitution and love. As some of these examples show, the expanding force of the drug vocabulary has the effect that many of its words widen their meanings in multiple directions and spread to casual language (cf. Rodríguez 2002: 39-41).

\section{Areas of change}

Apart from the fields already mentioned in the previous section, there are other productive areas of change in youth language.

There is a tendency to highten one's emotions, as shown by the effusive expressions and intensifiers added to the standard colloquial vocabulary: e.g. crazy ('amazing'), used by jazz enthusiasts in the 1950s, great and amazing, used in the 1960s and 1970s by promoters of pop music, groovy in the hippy era, and more recently neat and cool (cf. Sp. genial, mundial, fuerte and de puta madre). Along these lines we can place some vogue 
prefixes like super- and mega-, which occur frequently in both English and Spanish teentalk.

As a result of the close solidarity links established between members of an in-group there are innovations in the terms of address, as shown by terms such as chick, date and guy (cf. Sp. cheli, tronco, baby and pibe 'man/boy').

Although change in youth slang affects the vocabulary in the first place, this does not preclude it from having a certain effect on grammar. Thus, there are changes in word class, for instance from noun to adjective (it's a crap university [crap meaning 'bad']) and from adverb to adjective (he's too much, cf. Sp. es demasiado), in word order (it's enough good, instead of good enough), and in elliptical expressions (no I never for no I never did).

\section{Youth slang in London and Madrid teenage language}

\subsection{Preamble}

This section focuses on the use of teenage slang in London (cf. Stenström 2006; Stenström et al. 2002) and Madrid on the basis of data emerging from the two corpora mentioned above, COLT, collected in 1993 by a research team at the department of English at Bergen University, and COLAm, collected ten years later by a research team at the Romance department. With the exception of the time of collection, the corpora are largely homogeneous, since COLAm was compiled with COLT as a model. They consist of 431,528 and 401,318 words, respectively, ${ }^{2}$ and contain spontaneous, casual conversations between teenage boys and girls from different school districts representing high, middle and low socioeconomic backgrounds.

The conversations were recorded by the students themselves, more precisely by boys and girls who volunteered to record talk with their friends for a couple of days in various surroundings, such as the school yard, a park, at home, in the street, in a café, and so on. Ideally, the recording equipment would have been hidden from the cospeakers. This turned out to be impossible, however, as reflected in the very frequent references to the presence of the microphone, for instance it's a bloody microphone, isn't it and se va a comer el micrófono este tio ('this boy is going to eat the microphone'). As regards the further processing of the material, all the conversations were transcribed orthographically, and the final product, transcriptions with accompanying sound, is accessible for research on line. One way of studying the material from a sociolinguistic point of view is, for instance, by going from concordance output with specification of gender, age and social class to entire texts and sound. The match between the corpora is not perfect, however, when it comes to the specification of age ranges, which, in turn, only makes it possible to point to tendencies instead of drawing safe conclusions with respect to frequencies per age group (cf. section 6.2.2).

The question to be dealt with in this section is to what extent the use of slang in the two corpora agrees with the overall tendencies described in the previous sections. It has 
to be kept in mind, however, that the material is limited, which means that all the tendencies cannot be expected to be traced.

\subsection{The top ten}

As a starting point, let's consider the most frequently used slang words in each corpus. Two types will be considered: 'proper' slang, represented by non-taboo words, and 'dirty' slang, or taboo words (including those acting as swearwords), which, like proper slang words, are defined as slang in dictionaries such as Green (1998) for English, and León (1992) and Carbonell (2000) for Spanish.

The ten most frequent proper and dirty slang words in COLT and COLAm are listed in Table 1. Instances of the proper names Dick and Guy, which can also be regular nouns, are not included; nor are instances of (de) puta madre, included in the total for puta.

\begin{tabular}{|l|l|l|l|l|l|l|l|}
\hline C O L T & \multicolumn{2}{l|}{ C O L A m } & N \\
\hline Proper & $\mathbf{N}$ & Dirty & $\mathbf{n}$ & Proper & $\mathbf{N}$ & Dirty & \\
\hline stuff & 194 & fucking & 433 & tronco/a & $563 / 215$ & pumto/a & $108 / 598$ \\
\hline sad & 167 & Shit & 389 & chaval & 561 & joder & 576 \\
\hline wicked & 133 & fuck & 310 & mazo & 541 & mierda & 275 \\
\hline fancy & 99 & bloody & 282 & gilipollas & 184 & coño & 286 \\
\hline bloke & 84 & crap & 147 & mola & 156 & polla & 256 \\
\hline cool & 79 & bastard & 116 & movida & 112 & culo & 227 \\
\hline guy & 73 & bitch & 105 & flipado/a & $59 / 20$ & jo & 211 \\
\hline bum & 67 & piss & 100 & pedo & 74 & hostia & 174 \\
\hline rough & 64 & bollocks & 94 & guay & 62 & me cago en & 95 \\
\hline massive & 63 & dick & 79 & macho & 59 & (de) puta madre & 88 \\
\hline Total & $\mathbf{1 , 0 0 3}$ & & $\mathbf{2 , 0 5 1}$ & Total & $\mathbf{2 , 6 5 1}$ & & $\mathbf{2 , 8 9 4}$ \\
\hline
\end{tabular}

Table 1. The top ten proper and dirty slang words in COLT and COLAm. (Instances of the proper names Dick and Guy are not included.) Frequencies per 1,000 words: PROPER WORDS: COLT 2.3; COLAm 6.6. DIRTY WORDS: COLT 4.8; COLAm 7.2.

The Madrid teenagers are the more frequent slang users generally speaking; they use the top ten slang words almost twice as often as the London teenagers, more specifically 13.8 vs 7.1 per thousand words. The dirty words dominate in both corpora, where the Spanish figures are higher than the English. But it is obvious that the greatest difference between the two corpora is in the use of proper slang words. The reason for the dissimilarity is undoubtedly the Spanish teenagers' typical habit of constantly addressing each other by a vocative when talking to each other, such as pero qué dices tronco ('what do you say, man') and ¿no te das cuenta, chaval? ('don't you realize, mate?'). This habit is not shared by the English teenagers, who use man and mate much more sparsely. And neither bloke nor guy are used to address another speaker, but only used to talk about a third person. The girls are very seldom addressed by a vocative, unlike the Madrid girls. 
Another noticeable difference is that only the Spanish list contains words with a potential reference to drugs: movida ('agitated situation' or 'drug traffic'), flipado ('surprised' or 'affected by drugs') and rollo ('something boring' or 'hashish/marijuana'), while the English list contains more general words, with the 'empty' word stuff at the top. The next most frequent item mazo ('a lot') points to the Spanish teenagers' inclination for intensification, which is not reflected among the English top ten, with the near equivalent massive occupying the very last slot in the list. Another difference is reflected in the use of Sp. mola(r) vs Eng. fancy. Both mean 'I like', but while fancy only occurs in expressions such as Do you fancy Shelley? and You bloody fancy him?, molar is hardly ever used to express a liking for the other sex. One exception is a Alejandra le mola Leo ('Alejandra likes Leo').

\begin{tabular}{|c|c|c|c|c|c|c|c|c|c|c|c|}
\hline \multicolumn{6}{|c|}{$\begin{array}{llll}\mathbf{C} & \mathrm{O} & \mathrm{L} & \mathrm{T} \\
\end{array}$} & \multicolumn{6}{|c|}{$\begin{array}{lllll}C & O & L & A & m\end{array}$} \\
\hline Proper & Boys & girls & Dirty & boys & Girls & Proper & Boys & girls & Dirty & boys & girls \\
\hline Sad & 151 & 16 & $\begin{array}{l}\text { fuck- } \\
\text { ing }\end{array}$ & 281 & 152 & Chaval & 407 & 154 & puto/a & $71 / 444$ & $\begin{array}{l}37 / 1 \\
54\end{array}$ \\
\hline Stuff & 102 & 86 & shit & 255 & 134 & tronco/a & $330 / 31$ & $\begin{array}{l}233 / 18 \\
4\end{array}$ & joder & 278 & 298 \\
\hline Wicked & 92 & 41 & fuck & 218 & 92 & Mazo & 256 & 285 & polla & 206 & 50 \\
\hline Guy & 65 & 8 & bloody & 140 & 142 & gilipollas & 77 & 107 & coño & 163 & 123 \\
\hline Bloke & 55 & 29 & crap & 95 & 52 & Movida & 86 & 26 & $\begin{array}{l}\text { Mier- } \\
d a\end{array}$ & 125 & 151 \\
\hline Cool & 55 & 24 & $\begin{array}{l}\text { bas- } \\
\text { tard }\end{array}$ & 90 & 26 & Pedo & 17 & 57 & culo & 123 & 104 \\
\hline Fancy & 42 & 52 & piss & 65 & 35 & Mola & 64 & 92 & hostia & 113 & 61 \\
\hline Rough & 40 & 24 & dick & 63 & 20 & Flipado & 56 & 3 & jo & 83 & 128 \\
\hline massive & 39 & 19 & $\begin{array}{l}\text { bol- } \\
\text { locks }\end{array}$ & 58 & 31 & Macho & 39 & 20 & $\begin{array}{l}\text { me } \\
\text { cago } \\
\text { en }\end{array}$ & 74 & 21 \\
\hline Bum & 28 & 39 & bitch & 56 & 49 & Guay & 15 & 47 & $\begin{array}{l}\text { (de) } \\
\text { puta } \\
\text { madre }\end{array}$ & 56 & 32 \\
\hline Total & 669 & 340 & & $\mathbf{1 , 3 1 7}$ & 733 & & 1,378 & 1,208 & & 1,736 & 1,159 \\
\hline
\end{tabular}

Table 2. The top ten proper and dirty slang words in COLT and COLAm in relation to gender. (Total words - boys: 216,224; total words - girls: 200,391.)

The correspondence between English and Spanish is more even, at least in certain respects, when it comes to the dirty slang words. Eng. fucking and bloody, for instance, which are both used adjectively, are as common as the adjectively used Sp. puto/puta ('fucking', 'bloody'). Shit has the equivalent mierda. Sp. joder and the short form jo correspond to English fuck and bollocks, and polla ('penis') to the less frequent dick. On the other hand, neither Sp. hostia ('communion wafer') nor leche ('semen') have an English corresponding expression. The most noticeable difference is reflected in the Spanish emphatic expressions me cago en ('I don't give a damn about') and the highly emphatic (de) puta madre (as in es un tio de puta madre 'he's a fantastic guy'), with no English similar expressions among the top ten. 


\subsubsection{Gender differences}

The use of slang, and dirty slang in particular, is generally considered a typically male feature. This is also what the present study indicates, as displayed in Table 2 above.

Without going into detail, the total figures indicate that the boys are the most frequent slang users overall, twice as frequent as the girls in COLT, but with less difference between boys and girls in COLAm. Comparing the 'proper' word lists, one notices that fancy (I really really fancy Howard) and mola(r) (a ti te mola el ketchup 'you like ketchup', which express a liking for somebody or something, are girls' words, while sad and flipado, which express a slight dislike, are boys' words. The Spanish girls' predilection for mazo, mola and guay, too, seem to reflect a positive attitude. Among the 'dirty' words, the girls in COLT, somewhat surprisingly, use bloody more often than the boys (This traffic is bloody terrible!), while the girls in COLAm are the most frequent users of use joder and mierda (qué es esa mierda, 'what is this shit'). So, it is not entirely true to say that boys are the ones who use the dirtiest slang words.

\subsubsection{Age and gender differences}

Tables 3 and 4 show the distribution of slang words per age group and gender in the two corpora. $^{3}$

\begin{tabular}{|c|c|c|c|c|c|c|c|c|c|c|c|c|c|c|}
\hline \multicolumn{5}{|c|}{ Proper } & \multicolumn{3}{|c|}{ Dirty } & \multicolumn{4}{|c|}{ Total gender } & \multicolumn{2}{|c|}{ Total age } & \\
\hline \multirow[t]{2}{*}{ Age } & \multicolumn{2}{|c|}{ Boys } & \multicolumn{2}{|l|}{ girls } & \multicolumn{2}{|c|}{ boys } & \multirow{2}{*}{$\begin{array}{l}\text { Girls } \\
\mathrm{n}\end{array}$} & \multicolumn{2}{|l|}{ boys } & \multicolumn{2}{|c|}{ Girls } & & & \\
\hline & $\mathrm{n}$ & $\mathrm{p} / \mathrm{m}$ & $\mathrm{N}$ & $\mathrm{p} / \mathrm{m}$ & $\mathrm{n}$ & $\mathrm{p} / \mathrm{m}$ & & $\mathrm{p} / \mathrm{m}$ & $\mathrm{N}$ & $\mathrm{p} / \mathrm{m}$ & $\mathrm{n}$ & $\mathrm{p} / \mathrm{m}$ & $\mathrm{n}$ & $\mathrm{p} / \mathrm{m}$ \\
\hline $10-13$ & 153 & 0.4 & 41 & 0.1 & 390 & 0.9 & 39 & 0.09 & 563 & 1.3 & 90 & 0.2 & 653 & 1.5 \\
\hline $14-16$ & 409 & 0.9 & 211 & 0.5 & 816 & 1.9 & 554 & 1.2 & 1225 & 2.8 & 765 & 1.8 & 1990 & 4.6 \\
\hline $17-19$ & 40 & 0.09 & 70 & 0.2 & 70 & 0.2 & 105 & 0.3 & 110 & 0.3 & 175 & 0.4 & 285 & 0.7 \\
\hline Total & 602 & 1.4 & 322 & 0.7 & 1276 & 3.0 & 698 & 1.6 & 1898 & 4.4 & 1030 & 2.4 & 2928 & 6.8 \\
\hline
\end{tabular}

Table 3. Proper and dirty slang in relation to age and gender in COLT. (Total words 431,528.)

\begin{tabular}{|l|l|l|l|l|l|l|l|l|l|l|l|l|l|l|l|}
\hline Proper & \multicolumn{9}{l|}{ Dirty } & \multicolumn{3}{l|}{ Total gender } & $\begin{array}{l}\text { Total } \\
\text { age }\end{array}$ \\
\hline Age & Boys & Girls & boys & Girls & \multicolumn{2}{l|}{ boys } & Girls & \\
\hline & $\mathrm{n}$ & $\mathrm{p} / \mathrm{m}$ & $\mathrm{n}$ & $\mathrm{p} / \mathrm{m}$ & $\mathrm{n}$ & $\mathrm{p} / \mathrm{m}$ & $\mathrm{N}$ & $\mathrm{p} / \mathrm{m}$ & $\mathrm{n}$ & $\mathrm{p} / \mathrm{m}$ & $\mathrm{N}$ & $\mathrm{p} / \mathrm{m}$ & $\mathrm{n}$ & $\mathrm{p} / \mathrm{m}$ \\
\hline $13-14$ & 0 & 0 & 0 & 0 & 0 & 0 & 0 & 0 & 0 & 0 & 0 & 0 & 0 & 0 \\
\hline $14-15$ & 1232 & 3.1 & 1126 & 2.8 & 1426 & 3.6 & 1070 & 2.7 & 2658 & 6.6 & 2196 & 5.5 & 4854 & 12.0 \\
\hline $15-16$ & 86 & 0.2 & 33 & 0.1 & 254 & 0.6 & 57 & 0.1 & 340 & 0.8 & 90 & 0.2 & 430 & 1.0 \\
\hline $17-19$ & 0 & 0 & 0 & 0 & 0 & 0 & 0 & 0 & 0 & 0 & 0 & 0 & 0 & 0 \\
\hline Total & $\mathbf{1 3 1 8}$ & $\mathbf{3 . 3}$ & $\mathbf{1 1 5 9}$ & $\mathbf{2 . 9}$ & $\mathbf{1 6 8 0}$ & $\mathbf{4 . 2}$ & $\mathbf{1 1 2 7}$ & $\mathbf{2 . 8}$ & $\mathbf{2 9 9 8}$ & $\mathbf{7 . 4}$ & $\mathbf{2 2 8 6}$ & $\mathbf{5 . 7}$ & $\mathbf{5 2 8 4}$ & $\mathbf{1 3 . 0}$ \\
\hline
\end{tabular}

Table 4. Proper and dirty slang in relation to age and gender in COLAm. (Total words: 401,318.)

The fact that data representing age groups 13-14 and 17-19 are missing in the Madrid corpus may simply indicate that this data has not yet been transcribed. As a result, the heaviest slang users are found among the 14 to 16 year-olds in COLAm as well in COLT (Table 3). If the missing Madrid age groups had been represented, the Spanish dominance would obviously have been even greater. 
With respect to the occurrence of slang in relation to socioeconomic class, it turned out that the London boys and girls with an upper/middle class background were the most frequent users totally speaking, closely followed by those with a lower and middle class background, in that order. The reason is presumably that the majority of the upper/middle class boys and girls attended a public school in the outer London area and consequently formed a very close network where the use of slang flourished. In the Madrid corpus, the tendency was the opposite: the boys and girls with a middle and lower class background were by far the most frequent users, while the upper/middle class boys and girls were the least frequent users of slang.

\subsection{Functions}

The top ten slang words are discussed in terms of grammatical categories and pragmatic functions in the next two sections.

\subsubsection{Grammatical categories}

The grammatical categories represented by the top ten slang words are displayed in Table 5. Some of the words belong to more than one word class, which points to what is referred to as 'category shifts', i.e. shifts from one grammatical function to another. The order of word classes in the table is arbitrary, and the reason why, for instance, fuck and mazo are first placed in the noun category is simply that they happen to be used as nouns in the corpora as well as verbs and adverbs, respectively, while for instance cool and joder occur as verbs as well as adjectives and interjections, and so on. Going word class by word class, the words that have undergone a category shift are written in bold the first time they occur and are underlined in other functions, such as fuck as a verb and as an interjection and puto as a noun and an adjective. Words and expressions that are only written in italics, such as Eng. bastard and Sp. tronco/a, are used in only one grammatical function in the corpora.

\begin{tabular}{|c|c|c|}
\hline WORD CLASS & COLT & COLAm \\
\hline Noun & $\begin{array}{l}\text { fuck, bastard, dick, crap, } \\
\text { arse, bloke, piss, shit }\end{array}$ & $\begin{array}{l}\text { mazo, tronco/a, puto/a, chaval, } \\
\text { macho, movida, rollo, polla, } \\
\text { leche, mierda, flipado/a, guay, } \\
\text { hostia }\end{array}$ \\
\hline Verb & $\begin{array}{l}\text { fancy, fuck, crap, stuff, piss, } \\
\text { shit, cool, rough }\end{array}$ & molar, cagar,joder \\
\hline Adjective & 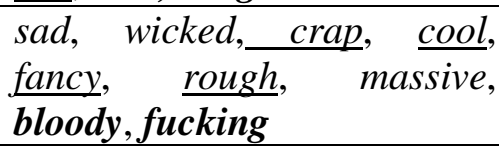 & guay, puto/a, flipado/a \\
\hline Adverb & bloody, fucking & mazo, guay \\
\hline Interjection & bollocks, fuck, shit, piss, crap & jo, joder, hostia \\
\hline Formulae & & (de) puta madre, me cago en \\
\hline
\end{tabular}

Table 4. Word classes. 
Eng. crap is particularly versatile: it serves as a noun (Did Joanne beat the crap out of you?), as an adjective (it's so crap innit?), as a verb (You really crap yourself) and as an interjection (A: Yeah, I do. - B: Crap!)

Sp. mazo is of special interest. It is sometimes followed by the particle de and sometimes occurs without $d e$, apparently with no change of function. This points to an ongoing grammaticalization process, with mazo changing from a noun ('large quantity') into an adverb, both with or without $d e$, as in the following examples:

NOUN: veía doble porque luego bebí mazo de alcohol ('I saw double because I had drunk a lot of alcohol'); ha traído mazo cruasanes ('she has brought a lot of croissants').

ADVERB with de: te juro que ya estoy mazo de asqueada ('I swear that I am extremely disgusted'); and without de: hostia, esto es mazo raro ('bugger, this is extremely rare'), el sol se calienta mazo y quema el suelo ('the sun is warming up and burns the ground').

Like the Spanish expressions (de) puta madre and me cago en, fixed expressions are also common in English youth language, in particular take the piss out of ('make fun of'), which was not used often enough to qualify for a place in the English top ten list, however (only 14 instances).

\subsubsection{Pragmatic functions}

From a pragmatic point of view, the following functions illustrated in Table 6 were identified:

\begin{tabular}{|l|l|l|l|l|}
\hline & \multicolumn{2}{|c|}{ Proper words } & \multicolumn{2}{c|}{ Dirty words } \\
\hline Function & COLT & COLAm & COLT & COLAm \\
\hline Term of address & bloke, guy & $\begin{array}{l}\text { tronco, } \\
\text { chaval, } \\
\text { macho }\end{array}$ & & \\
\hline Characterizer & $\begin{array}{l}\text { sad, wicked, } \\
\text { flipadol, rough } \\
\text { guay }\end{array}$ & mola, mazo & $\begin{array}{l}\text { bloody, } \\
\text { fucking }\end{array}$ & $\begin{array}{l}\text { (de) puta madre, } \\
\text { que te cagas } \\
\text { puto/a, me cago } \\
\text { en }\end{array}$ \\
\hline Intensifier & $\begin{array}{l}\text { massive, } \\
\text { fancy }\end{array}$ & bitch & $\begin{array}{l}\text { bollocks, shit, } \\
\text { crap, piss }\end{array}$ & joder, jo, mierda \\
\hline Insult & Exclamation & movida & & polla \\
\hline Euphemism & bum & & fuck & \\
\hline Set marker & stuff & & & \\
\hline Multi-functional & & & & \\
\hline
\end{tabular}

Table 6. Pragmatic functions. 
- TERMS OF ADDRESS can either be used to talk about somebody: Me and my mate just gonna sit over there, and se la comió el chaval ('The guy ate it') or, as a vocative, i.e. be directed to somebody: ¿Qué dices, chaval? ('What did you say, mate?'). While the vocative function is rare in COLT, despite one potential vocative among the top ten proper words, notably bloke (Hey bloke get out your beer), and three among the dirty words, bastard, bitch and dick (You Irish bastard!, You old bitch, You dick.), they are extremely frequent in COLAm (e.g. cómo va chaval ('how are you mate'), where examples illustrating the non-vocative function, on the other hand, are rare. One is $y$ ahora el chaval no sabe qué hacer ('and now the guy doesn't know what to do').

- CHARACTERIZERS reflect the speaker's opinion about another person: You're a sad bastard Julian; Estás todo flipado ('You're completely nuts'). Only proper slang words are represented among the top ten.

- INTENSIFIERS have a heightening effect. They are realized by proper slang words (it's gonna be a massive orgy and estoy mazo cansado hoy 'I'm terribly tired today') as well as by dirty slang words (it's really bloody annoying and hace un frío que te cagas 'it's cold as hell').

- INSULTS are rude or offensive remarks directed to a co-speaker or said about a person who is not present. They are by nature realized by dirty slang words, for instance I know she's a bitch and es un puto cerdo ('he's a bloody pig').

- EUPHEMISMS are used in order to avoid a word that might be offensive, rude or unpleasant, here represented by bum instead of arse: get your big bum her.

- SET MARKERS are vague items which make it possible to avoid being overexplicit by spelling out things that are fairly obvious, such as the guy who plays racquets and squash and stuff. The word shit (like that) can be used for the same purpose: you know universities and colleges and shit, and stuff and shit can cooccur: And she said er, did she go to your mum, oh you've done a good job and, and shit and stuff.

- MULTIFUNCTIONAL ITEMS occur predominantly in fixed phrases, such as English fuck: in fuck off, fuck you, fuck about, what the fuck and oh fuck, and Spanish polla: es la polla ('it's unusual'); comer la polla ('have a blow job'); partirse la polla ('roar with laughter'), iy una polla! ('bollocks!').

\section{Linguistic mechanisms}

Of the linguistic mechanisms described in Section 3, the first two, i.e. change of form and change of meaning, seem to have affected the top ten slang words to a greater extent than change of code and change of register. A search for less frequent slang words gave a slightly different picture. 


\subsection{Change of form}

The interjection jo ('shit, bollocks'), the short eufemistic version of the verb joder is an example of CLIPPING with only part of the original word retained. It may indicate irritation, as in jo cómo ladra el perro ('phew, how the dog barks') or surprise, as in jo yo qué sé, perdóname ('oh how should I know, I'm sorry'), or intensification as in jo qué vistas más guapas ('wow, what a nice view'). A less frequent word which is a form of clipping is anfetas, short for anfetamina.

Among the top ten slang words in COLT there are no examples of clipping. But going beyond the top ten we find examples such as mag for 'magazine', Paki for 'pakistani', prep for 'preparatory school', san for 'sanatorium' and nan for 'nanny'.

ACRONYMS are represented in COLAm by $\mathrm{COU}$ for 'Curso de Orientación Universitaria', which is mentioned a few times. One example is no te van a catear $C O U$ ('You won't fail COU').

There are two examples of SUFFIXATION among the top ten in COLAm, notably movida ('fuss', 'partying') from the verb mover ('move') and flipado/a ('high'), from the verb flipar ('affected by drugs'). Examples are eso es una movida y y y están tirando botellas ('this is a commotion and and and they are throwing bottles around') and estás algo flipado tú ('you are a bit high'). In addition to the top ten, we find a large number of slang words ending in -ado/a, which is a very productive suffix, such as putada ('nastiness, pity'), from puta ('prostitute'): nació el ocho de diciembre, que es una putada ('he was born on the eighth of December, which is a pity'), mosqueada ('irritated'), from the verb mosquear ('irritate'): claro tio yo toda mosqueada ('of course man I was really irritated'), zumbado ('crazy'), from the verb zumbar (literally, 'hit'): esa gente está toda zumbada ('those people are completely mad'): y yo (to|todo) (acojonao|acojonado ('and I [was] dead scared'), and me ha achuchado un perrilla así ('he set the little bitch on to me like that'). Another suffix, but far less common, is -udo, as in pelotudo ('stupid') and cornudo ('cuckold'). Others are -ón/a (mamón 'bastard, swine'), -illo/a (mierdecilla 'small shit'), -dor/a (consolador 'dildo').

\subsection{Change of meaning}

Neither English motherfucker and motherfucking nor Spanish (de) puta madre should be interpreted literally. All three are used as intensifiers, the first two with a negative undertone, as in Beat that one motherfucker! and You motherfucking shit (cf. Green 1998), although often said jokingly with no intention to offend. De puta madre, on the other hand, has a positive undertone, as illustrated in tuvo un año de puta madre en COU ('he had a marvellous year at COU') and tengo una novia que es de puta madre ('I have a girlfriend who is fantastic'). The adjectives sad, wicked and rough in COLT have all undergone a change of meaning: sad from 'unhappy' to 'hopeless' (fucking sad you are!, wicked from 'unpleasant', 'awful' to 'excellent', 'wonderful' (She's a wicked singer!), and rough from 'lacking good manners' to 'excellent', 'great' (Steven's hair's rough isn't it.). One example from COLAm is movida, which is related to the verb 
moverse ('move') and was originally used to mean 'agitated situation' and now often means 'agitated situation', as in hostia qué movida ('god what a hullabaloo'). Another example is pedo, originally meaning 'fart', which in its slang version is used for 'intoxication', as in me pillé un pedo muy gordo ('I got really drunk').

The English noun bastard was originally used for 'child of unmarried parents', but is now said about an 'unpleasant person' (a complete miserable bastard like Patrick). Bitch was originally used to show disapproval of a woman's sexuality, as in one single example in COLT (Jade thinks she a right horny bitch don't she?), while today's use focuses on her personality (People think I'm a bitch cos I speak my mind ). The noun dick, which was first used to refer to 'man' as a generic term, is now used for 'penis' (dick hard as a rock.) but, at least in COLT, more frequently with reference to a 'foolish man' (Acts like a complete dick).

In COLAm, the noun leche ('semen') occurs in numerous metaphors, e.g. es la leche el minidisc ('the minidisc is super'), con cara de mala leche ('looking malevolent'), me cago en la leche ('I don't give a damn'), while hostia, originally 'communion wafer', indicates a high degree in expressions such as hacía un buen tiempo de la hostia ('the weather was super'), se ha pegado una hostia ('he had a very bad crash') and a toda hostia ('very fast'). Going beyond the top ten, we find the adverbial mogollón, which used to mean 'gratuitous' and now means 'a lot' (voy a hacer un mogollón de copias 'I will make a lot of copies') or 'much' (estudia mogollón 'she studies a lot').

\section{Subject matters}

The subject matters that are most richly represented in the London and Madrid corpora are sex and physical attraction, drugs (especially drinking and smoking), music, and pastimes. School (including subjects and exams) is an all-pervading theme, and there are constant comments on the recording situation in both corpora.

\subsection{Subject matters reflected in the top ten}

Among the top ten, the first two fields are represented in COLAm by joder, polla, macho (sex) and movida and flipado (occasionally drugs), while only words related to sex occurred in COLT, e.g. fancy, fuck and dick. Music terms and school slang did not occur among the most frequent slang words.

However, Sp joder never occurs in its original sense (' have sexual intercourse with') in the corpus, only as a rather weak exclamation: joder pues me cago en su puta madre ('shit I don't care about his bloody mother') but also in the sense of 'mess up': entonces esto se puede joder más fácilmente ('then this can easily be fucked up'). Nor are puto and puta used in the sense of 'homosexual' or 'prostituta', but only as coarse intensifiers, and so is coño ('vagina'): si mi padre de una puta vez me deja hacerme el puto tatuaje o qué coño pasa ('if my father for once lets me have the bloody tattoo or 
what the hell is going on'). COLAm contains several expressions involving la polla that should be interpreted figuratively in addition to its original sense ('penis'), e.g. es la polla este disco ('this disc is unbelievable').

Considering the 'proper' word list, we find that Sp. movida is only rarely used to refer to drugs in the corpus, e.g. nos dijo queréis unos chupos de una movida rarísima ('he said would you like to taste a very uncommon drug') but that it is generally used in the sense of 'agitated situation', as mentioned above, as in joder qué movida ('shit what a mess'). According to León (1992), the word flipado refers to a person who is affected by a drug or about somebody who is surprised, astounded. The instances of flipado in COLAm very seldom correspond to this definition. One example is yo me he quedado flipado ('I was astounded'), but generally, it is rather a matter of (slight) abuse: cómo se llama el flipado ('what's the name of this thickhead'): es un puto flipado de mierda ('he's a bloody asshole'). ${ }^{4}$

As regards English, the verb fancy is often used to express sexual attraction, and the object of attraction is often mentioned by name, e.g. such a dilemma. I do actually quite fancy Jimmy, yeah, I don't want to but I do. The Spanish verb molar ('like') is used in a much more neutral sense in the vast majority of cases, e.g. lo que me mola de este examen es que ... ('what I like about this exam is that...') or simply eso mola ('this is great'). One of the very few exceptionswhere mola is used with sexual connotations is $a$ ti te mola el Truje ('you fancy Truje').

Considering its origin, English fuck is surprisingly seldom used in the sense of 'having sex with' (Are you gonna fuck her); it is generally used as an exclamation (Fuck!) or in combinations such as fuck you!, fuck off!, fuck up, give a fuck, oh fuck and who/what/where/when the fuck? Denigrating expressions are particularly frequent in COLT, represented by bitch, bastard and dick among the top ten, in this order of frequency. These expressions are either said directly to an addressee (stupid little bitch; you fat bastard; you fucking dick) or said about somebody who is not present (Nick's such a bitch; he's such a flipping bastard; she's a dick). Only two denigrating expressions are represented among the Spanish top ten: gilipollas (cállate gilipollas 'shut up stupid') and flipadola (es un flipado de cojones 'he's a bloody fool').

\subsection{Subject matters reflected in the less common slang words}

In addition to the top ten slang words, searches in the corpora for less common slang words yielded many of the terms mentioned in Section 3, in particular terms referring to sex and drugs. In contrast, money, fear (of others) and self-aggrandizement, mentioned by Green (this volume) as basic themes, are not typical themes in the London and Madrid adolescents' language, where denigrating expressions are strikingly frequent.

- SEX

Eng. shag and screw ('have sexual intercourse with') correspond to Sp. follar (yo tengo que follar en Nochevieja 'I have to have sexual intercourse on New Year's Eve'), Eng. boobs ('female breasts') corresponds to Sp. tetas. Eng. queer ('homosexual') is 
equivalent to Sp. maricón, which is often used as a general insult (qué maricón tío 'what a bastard, man'). Eng. fanny, cunt and pranny ('vagina') correspond to Sp. coño and Eng. cock ('penis') to Sp. polla. Eng. wank ('masturbate') is matched by Sp. hacerse una paja ('to masturbate'). What seems to be missing in COLAm is an expression corresponding to Eng. snog ('to kiss amorously'), as in I'll probably end up snogging with him at my party.

- DRUGS

Quite a few words in the corpora belong to the area of drugs. The English word pot, for instance ('cannabis'), as in I'm smoking pot, has the Spanish correspondence hierba (quién fuma hierba 'who smokes marihuana'), while speed ('amphetamine') corresponds to Sp. anfeta, which is short for anfetamina. The London teenagers use joint ('a cannabis cigarette'), which is what the Madrid teenagers call porro, toque or pito (thouth the last word is also more generally used in its literal sense, as a shortening of pitillo 'cigarette'). The English word junkie for 'heroin addict' has been adopted in Spanish as yonqui; trip ('a hallucinatory experience caused by taking LSD or any other psychedelic drug') corresponds to colocón in COLAm, while the form trip does not occur at all, nor does English dope for 'drug'. The expression get blast up ('to become affected by drugs') might be matched by flip, which occurred in a phrase borrowed from the 'Spanglish' expression don't flip darling ('don't get overexcited'), which confirms that flipar is a Spanish adaptation of the English verb flip used as a slang term meaning 'get excited'. Finally, the words canuto and chicle are used as synonyms for 'hashish'.

\section{Concluding remarks}

We fully agree with Crystal (1987: 53), who says that ' $[\mathrm{t}]$ he chief use of slang is to show that you're one of the gang!'. This is amply reflected in the two youth language corpora compared in this paper, and not least in the top ten proper and dirty slang words, though not exactly in the same way. Take for instance the Spanish youngsters' overwhelming use of the vocatives tronco/tronca and chaval as a kind of intimacy signals and their trendy use of mazo and mola as intensifying words. It is also reflected in the rich use of dirty words by both youth groups, used as mock insults (Eng. bastard, Sp. cabrón) and/or to create a chummy atmosphere.

As a look at the entire corpora reveals, the conversations are mainly about sex and physical attraction, fashion and physical culture, music, drugs, school and leisure activities, partly reflected in the top ten lists, for instance Eng. fancy, a verb that is particularly frequent when girls talk about boys. Other words belonging to the sex domain are Eng. fuck and dick, and Sp. putola and polla, while movida and flipado might belong to the domain of drugs, though most of these words are not used in their original sense in the corpora. The study shows that, while the Spanish teenagers most often talk about drugs, the English teenagers more often talk about sex. Moreover, in addition to the Spanish teenagers' frequent use of vocatives, they also tend to use 
intensifying expressions more often than the English, who, on the other hand, are the most frequent users of denigrating expressions, albeit with a chummy effect.

With respect to the linguistic mechanisms described in the first part of the paper, only change of form and change of meaning were observed among the top ten slang words in COLT and COLAm. The Spanish interjection jo, for instance, which is a result of clipping (a shortening of joder), is an example of change of form, while English sad, wicked and rough, which are used in a transferred sense in the corpus, illustrate a change of meaning.

Although the general tendency seems to be that the use of slang is first and foremost a male phenomenon, de Klerk (2004) suggests that it is probably not the sex of the speaker alone that influences slang usage but also, and perhaps more importantly, his/her age and scholastic environment'. That age is an important factor is supported by the results of this study, which showed that the heaviest slang users were the 14 to 16 year-olds in both corpora. It also showed that the school environment in combination with socioeconomic background plays an important role in that, although the use of slang was most prominent in a London school borough with students from the lowest socioeconomic class, upper middle class students were the next most frequent users. This seems to be due to the fact that those students, who went to the same public school, formed a very close network with their own linguistic (and behavioural) code. But there is no doubt, according to this study, that the use of slang, including the dirtiest slang, is a boys' thing in the first place.

\section{Notes}

1. For a full discussion of rhyming slang, see Lillo (1998, 2008, 2010, 2012).

2. The COLAm corpus is growing and now consists of 432,140 words, i.e. after the completion of this paper.

3. The reason why 'age plus gender' searches do not give exactly the same figures as single searches (age alone or gender alone) is that some information seems to get lost when searches are combined.

4. Literally, 'he's a bloody flipped-out shit'.

\section{References}

Andersson, Lars-Gunnar and Peter Trudgill (1990): Bad Language. Oxford: Blackwell. Carbonell Basset, Delfín (2000): Gran diccionario del argot. El Soez. Barcelona: Larousse. Corpus Oral de Lenguaje Adolescente de Madrid (COLAm) <http://gandalf.aksis.uib.no/cola>. Crystal, David (1987): The Cambridge Encyclopedia of Language. Cambridge: Cambridge University Press. de Klerk, Vivian (1990): “Slang: A Male Domain?”. Sex Roles 24, 9/10: 589-606. Eble, Connie (1996): Slang and Sociability. Chapel Hill: University of North Carolina Press. 
Eckert, Penelope (1997): “Why Ethnography?”. In Kotsinas, Ulla-Britt, Anna-Brita Stenström and Anna-Malin Karlson, eds., Ungdomsspråk $i$ Norden. Föredrag från ett forskarsymposium. Stockholm: MINS 43, 52-62.

Green, Jonathon (1998): Cassell's Dictionary of Slang. London: Cassell.

Halliday, Michael (1978): Language as Social Semiotic. London: Arnold.

Hebdige, Dick (1984): Subculture. The Meaning of Style. London: Methuen. (1st ed. 1974).

León, Victor (1992): Diccionario de argot español y lenguaje popular. 2nd ed. Madrid: Alianza Editorial.

Lillo, Antonio (1998): Estudio lingüístico del 'rhyming slang'. Unpublished $\mathrm{PhD}$ thesis. University of Alicante.

(2008): "Covert Puns as a Source of Slang Words in English". English Studies 89, 3: 319_ 338.

(2010): "Did Dublin's Ben Lang Ever Die?: On the Revival of Rhyming Slang in Modern Dublinese". Lebende Sprachen 55, 1: 123-138.

(2012): "Nae Barr's Irn-Bru Whit Ye're Oan Aboot: Musings on Modern Scottish Rhyming Slang". English World-Wide 33, 1: 69-94.

Longman Dictionary of Contemporary English. 1987. London: Longman.

Marcuse, Herbert (1972): An Essay on Liberation. London: Penguin. (1st ed. 1969).

Murray, Thomas E. (1996): "Spanish Loanwords in Contemporary American English Slang". In Félix Rodríguez, ed., 1996, 103-137.

Rodríguez, Félix, ed. (1996): Spanish Loanwords in the English Language. Berlin / New York: Mouton de Gruyter.

— (1998): Review of Slang and Sociability (by Connie Eble, University of North Carolina Press, 1996), Journal of English Linguistics 26, 3: 247-265.

— ed. (2002): El lenguaje de los jóvenes. Barcelona: Ariel.

- (2002): "Lenguaje y contracultura juvenil: anatomía de una generación". In Félix Rodríguez, ed., 2002, 29-56.

- (2005): Diccionario de terminología y argot militar. Vocabulario del soldado y la vida del cuartel. Madrid: Verbum.

Stenström, Anna-Brita (2006): "From Slang to Slanguage". In A. Feyvesi, T. Kis and J. Várnal, eds., Revue d'Études Françaises. Department of French. Centre for French Studies. Eötvös Loránd University, Budapest, 89-108.

Stenström, Anna-Brita, Gisle Andersen and I. Kristine Hasund, 2002. Trends in Teenage Talk. Corpus Compilation, Analysis and Findings. Amsterdam: Benjamins.

The Bergen Corpus of London Teenage Language (COLT) <http://gandalf.uib.no/colt>.

Thorne, Tony (1997): Dictionary of Contemporary Slang. 2nd ed. London: Bloomsbury. (1st ed. 1990).

Vigara Tauste, Ana María (2002): “Cultura y estilo de los 'niños bien': radiografía del lenguaje pijo”. In Félix Rodríguez, ed., 2002, 195-242. 